\title{
Geographic location and contemporary state borders of Bulgaria
}

Localização geográfica e fronteiras estatais contemporâneas na Bulgária Localisation géographique et frontierès étatiques contemporaines à Bulgarie Ubicación geográfica y fronteras estatales contemporáneas en Bulgaria

\section{Slavi Dimitrov}

\section{(2) OpenEdition}

\section{Journals}

\section{Electronic version}

URL: http://journals.openedition.org/espacoeconomia/1857

DOI: 10.4000/espacoeconomia.1857

ISSN: 2317-7837

\section{Publisher}

Núcleo de Pesquisa Espaço \& Economia

\section{Electronic reference}

Slavi Dimitrov, «Geographic location and contemporary state borders of Bulgaria », Espaço e Economia [Online], 7 | 2015, Online since 12 April 2016, connection on 10 December 2020. URL : http:// journals.openedition.org/espacoeconomia/1857 ; DOI : https://doi.org/10.4000/espacoeconomia. 1857

This text was automatically generated on 10 December 2020.

\section{(C) 10}

Espaço e Economia - Revista brasileira de geografia econômica est mise à disposition selon les termes de la licence Creative Commons Attribution - Pas d'Utilisation Commerciale - Partage dans les Mêmes Conditions 4.0 International. 


\title{
Geographic location and contemporary state borders of Bulgaria
}

\author{
Localização geográfica e fronteiras estatais contemporâneas na Bulgária \\ Localisation géographique et frontierès étatiques contemporaines à Bulgarie \\ Ubicación geográfica y fronteras estatales contemporáneas en Bulgaria
}

Slavi Dimitrov

\section{Introduction}

1 In this paper, the object of research is the geographical location of Bulgaria, and the possibilities that it offers. The geographic location of Bulgaria reflects its spatial relation to different geographic objects of economic importance (countries, regions, seas, big rivers, straits, etc.). It is a category which consists of mutually related and mutually dependent elements (subcategories). Some of the subcategories are changeable (economic and political state), others are comparatively stable (astronomical and natural environment).

2 Bulgaria is situated in South-East Europe, in the North-East part of the Balkan Peninsula. So, it is an European and Balkan country, and a country which belongs to the Black Sea and the Danube regions. Besides, it lies at the crossroad between Europe, Asia, and Africa, close to world markets and regions, rich in raw materials, which predetermines its strategic place on the maps of Europe and the Balkan Peninsula (Fig.№1). The geographic position of Bulgaria explains the interest of its neighbours, USA, Russia, and the WestEuropean countries to its territory, in the past and nowadays (ГЕОГРАФИЯ..., 1997). 
Figure 1: Geographic Location of Bulgaria

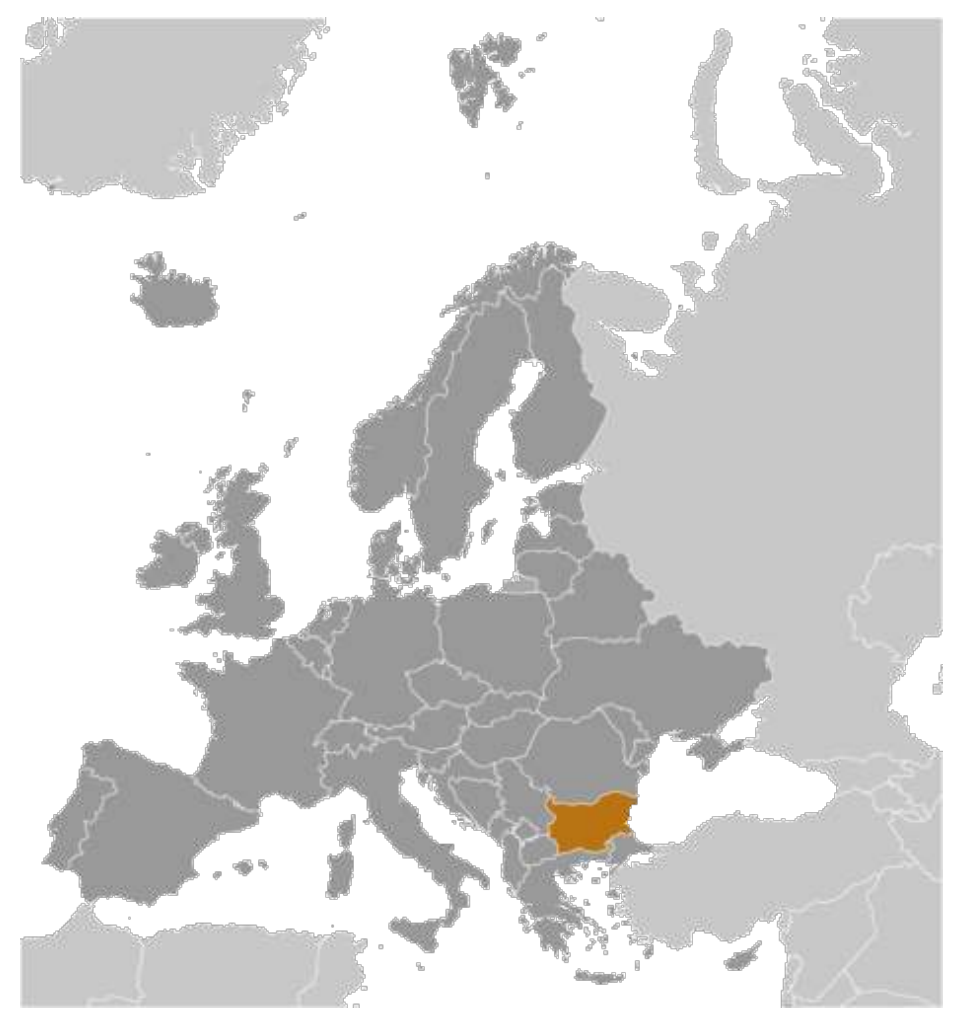

Source: Central Intelligence Agency (CIA) - World Factbook, 2014.

\section{The location of a country can be geographical, geoeconomic, and geopolitical.}

The astronomical geographic location is defined in relation to the Greenwich meridian (longitude) and the equator (latitude). The astronomical geographic location of Bulgaria is defined by its endmost points (Table №1). The length of the country between these points is about $520 \mathrm{~km}$ And the width - about $330 \mathrm{~km}$. Bulgaria is closer to the equator than to the North Pole, which determines its climate and natural conditions. The country is situated in the southern part of the North Temperate Zone, with some subtropical influence over its climate. This location in the transitional zone between the two zones gives its reflection over the climate, the soils, the flora and the fauna.

Table 1: Coordinates of Bulgaria's endmost points

\begin{tabular}{|l|l|l|}
\hline Point & North latitude & East longitude \\
\hline $\begin{array}{l}\text { Northern } \\
\text { The mouth of the Timok River }\end{array}$ & $44^{\circ} 12^{\prime}$ & $22^{\circ} 40^{\prime}$ \\
\hline $\begin{array}{l}\text { Southern } \\
\text { Veykata peak, The South-East Rhodopes }\end{array}$ & $41^{\circ} 14^{\prime}$ & $25^{\circ} 17^{\prime}$ \\
\hline
\end{tabular}




\begin{tabular}{|l|l|l|}
\hline $\begin{array}{l}\text { Western } \\
\text { Kitka peak, Kraishte }\end{array}$ & $42^{\circ} 19^{\prime}$ & $22^{\circ} 21^{\prime}$ \\
\hline $\begin{array}{l}\text { Eastern } \\
\text { CapeShabla }\end{array}$ & $43^{\circ} 32^{\prime}$ & $28^{\circ} 36^{\prime}$ \\
\hline
\end{tabular}

source: Пенин, Р. ПрироднагеографиянаБългария, С., Булвест, 2007.

4 The natural geographical location is closely related to the astronomical location and reflects the relation between the territory of the country and the important elements of physical geography: oceans, seas, navigable rivers, mountain chains, plains, etc. The hydrosphere elements that influence the territory of Bulgaria are: the Atlantic Ocean, the Black Sea, and the Mediterranean Sea. The Atlantic Ocean and the Mediterranean Sea are important climate factors because huge air masses originate over them and are carried away by the Icelandic Low and Mediterranean tropical-like cyclone. The Mediterranean influence is decisive for the climate in the southern parts of the country. The influence of Black Sea is tangible in the zone which is situated 40 kilometers inland from the shore. That influence determines the specific Black Sea climate, the diverse flora and fauna. The Danube River, as a factor of physical geography, is very important with its water resources, which are used for irrigation, production of electricity, water supply for the factories, and fishing; as well as for its diversity of species.

5 The natural geographic location reflects the influence of the mountain chains situated outside the Bulgarian territory, too (the Dinarides and the Carpathian Mountains). The Dinaric Alps and the Pindus isolates the country from the influence of the Adriatic Sea and the West part of the Mediterranean Sea; and the Carpathian Mountains hold up the oceanic air masses form North-West (in this way, they create a rain shadow in the Danubian Plain). In conclusion, we can say that, due to the favourable natural geographic location of Bulgaria, a change, from north to south, in the climate, soil, and vegetation components of the natural environment is observed, which favours its economic development (ГЕОГРАФИЯ..., 2002).

6 The economic geographical location comprises transport, trade, and touristic geographic location. It shows the relation between Bulgaria and objects of economical significance (regions rich in raw materials, markets, international highways, connections with other countries).

7 The Bulgarian geo-economical localization, in terms of transport, is very favourable. Being a part of East-central Europe, Bulgaria is a crossing point and a transitional zone between West Europe, the Near and the Middle East, and the Mediterranean region. The country is crossed by the routes from the Commonwealth of Independent States to South Europe and Africa and several other transport corridors: Germany - Czech Republic Hungary- Romania - Bulgaria - Greece/Turkey (through the Danube Bridge); Albania Italy - Slovenia - Croatia - Serbia - Macedonia -Bulgaria (which connects the Adriatic and the Black Sea); as well as the Rhine - Main - Danube Canal. The international highways from West and Central Europe (through Belgrade - Sofia - Svilengrad) to the Near and the Middle East; from the Baltic Sea (through Moscow-Kiev -Bucharest - Ruse - Sofia Thessaloniki) to the Aegean Sea and to the Adriatic Sea (Sofia - Skopje - Durrës) also go through the country. Of great importance is the route ConstanȚa-Varna-Burgas - 
Tzarevo - Malko Turnovo- Istanbul. Bulgaria is connected to the Trans-European Transport Network through the routes Berlin - Prague - Budapest -Sofia - Thessaloniki Istanbul and Durrës-Tirana - Skopje-Sofia - Varna - Burgas. Besides the automobile transport, the main transport directions are served by railroads, too.

Besides, the long Black Sea coastline of Bulgaria connects it with all countries from the Black Sea Region. The Danube River connects all East-European countries to the WestEuropean waterways. The importance of the river grew after the above-mentioned Rhine - Main - Danube Canal was put into operation (September $25^{\text {th }}, 1992$ ).

Bulgarian customs and border checkpoints also help the functioning of the transport network. In 2015, the total number of the checkpoints is 23 (5 on the Serbian border, 3 on the Macedonian border, 6 on the Greek border, 2 on the Turkish, 5 on the Romanian, and 2 on the Black Sea cost) (Fig. №2).

Figure 2: Contemporary borders of Bulgaria, border checkpoints, and free trade zones

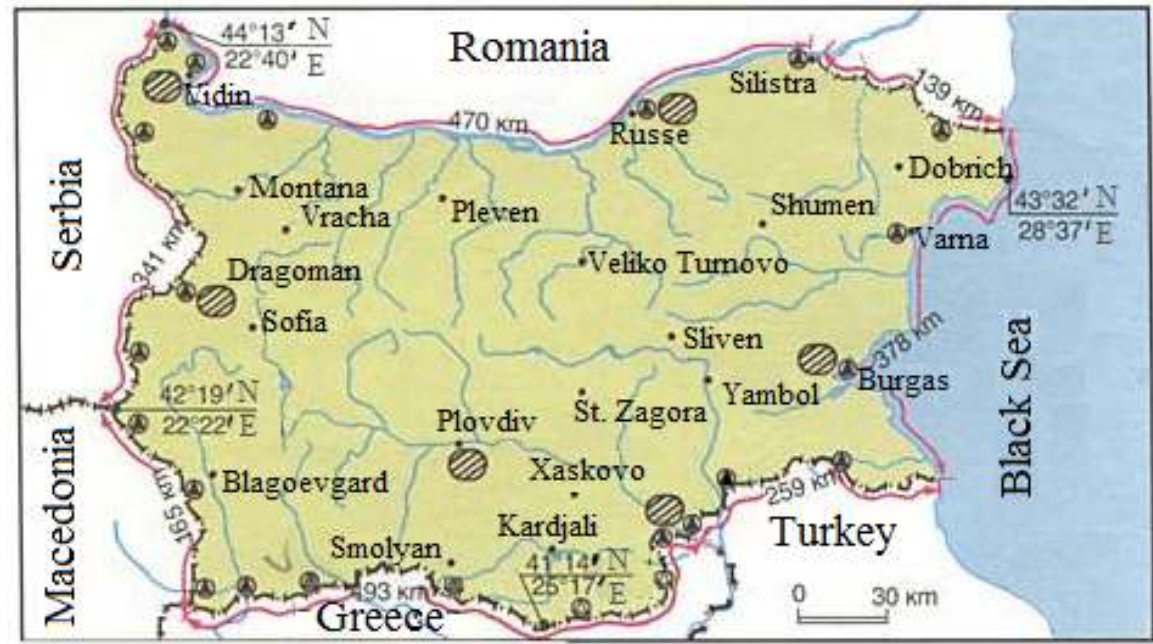

$\longleftarrow 470 \longrightarrow$ Lenght of border, $\mathrm{km}$

$\frac{44^{\circ} 13^{\prime} \mathrm{N}}{22^{\circ} 40^{\prime} \mathrm{E}} \quad$ End point with geographic coordinates

(D) Border checkpoint

Free Economic Zone

SOURCE: OWN PRODUCTION

The number of the border checkpoints and its relation to the total length of the border can be used as a measure of the frequency of cross-border connections only to some extent. It is logical that connections with neighbour countries prevail over connections with other countries. Generally speaking, the more developed two or more countries are, the more intensive the contacts between them are, that is why the number of the checkpoints on the border between them is more numerous, especially if it is a land border (колЕв, 2008). Such is the case for the Spanish-Portuguese border which is the oldest one in Europe, and between two checkpoints there is a distance of $16 \mathrm{~km}$ (димитров, 2015); from Table 2 one can see that the shortest sectors between two border checkpoints are on the border between Bulgaria and Macedonia, and the longest ones are on the Bulgarian-Greek border. 
Table 2: Average length between two border checkpoints on the Bulgarian border - 2015

\begin{tabular}{|l|l|l|l|l|l|l|}
\hline Neighbour country & Romania & Turkey & Greece & Macedonia & Serbia & The Black Sea \\
\hline Length, km & 60,8 & 80,0 & 82,3 & 49,3 & 63,6 & 126,0 \\
\hline
\end{tabular}

SouRcE: Колев, Б., Националното географско пространство на Република България, „Херон прес", София, 2008, р. 135.

11 The development of Bulgaria as a member of the European Union, alongside with all other necessary reforms, will increase the connections between Bulgaria, its neighbour countries, and the countries from the whole Europe (колЕв, 2008).

The Economic geographic location changes throughout different historical stages. Nowadays, Bulgarian foreign trade is oriented towards European countries. The country profits from its membership in the World Trade Organization (since 1996), the Organization of the Black Sea Economic Cooperation, the economic organizations of the United Nations, and the European Union (since 2007). Very important is the transit transport of people, goods, and information through the country. The free economic zones in Dragoman, Vidin, Burgas, Ruse, and Plovdiv bring some import incentives that stimulate development of trade in the country (ГЕОГРАФИЯ, 2002).

13 The favourable location of Bulgaria is a factor of great importance for its development into a world tourist destination. In the country, there are great opportunities for both the transit and the active recreational international tourism due to the significant natural, cultural, and historical sightseeings. In 2014, 7.3 million foreign tourists visited it (нСи, 2014).

The political geographic location of Bulgaria is formed by its relations with different political communities which reflect Bulgaria's political connections, and outline its borders.

The importance of the contemporary strategic and geopolitical location of the country should be estimated in the context of the democratic changes in East Europe in the 90's of the $20^{\text {th }}$ century. After the collapse of the Warsaw Pact, Bulgaria looked for new ways to ensure its military and political stability, and for a new place in the Balkan region, shaken by conflicts. The new military and political conditions required the creation of a new geopolitical strategy, new political priorities and principles for the country which should guarantee good relations with its neighbours. The present geopolitical situation, and its entry into NATO in 2004, gives the country new advantages.

The political geographic situation of Bulgaria is in close relation to its political borders. The political borders of a country depend on the concrete stage of its social and political development (КАРАСТОЯНОВ, 1997).

Friedrich Ratzel (РАТЦЕЛ,1897), one of the founders of the modern political geography, considers the state borders to be a 'peripheral organ of the state, organically connected to the country's territory'. Dronchilov (дРончилов, 2003) states that the borders of a country completely reflect its historical fate.

18 The notion 'political borders' acquired a new meaning at the present stage of social and economic development. Due to the opposition between East and West Europe, until 1989 the Bulgarian state borders were used rather as barriers. That led to political and 
economic isolation of Bulgaria regarding the developed European countries, and depopulation of frontier territories. After 1989, the character and the functions of the political borders changed. Instead of dividing, they began unifying the countries, trying to integrate the interest, the capitals, and the efforts of neighbour countries, which is characteristic of the relations between democratic states. The total length of the Bulgarian borders is $2245 \mathrm{~km}$. $1181 \mathrm{~km}$ of them are land borders, $686 \mathrm{~km}$ are river borders, and $378 \mathrm{~km}$ - sea borders (see Table №3).

Table 3: Length of Bulgarian state borders in kilometres

\begin{tabular}{|l|l|l|l|l|}
\hline Border & Totally & Land border & River border & Sea border \\
\hline With Romania to the North & 609 & 139 & 470 & - \\
\hline With the Black Sea to the East & 378 & - & - & 378 \\
\hline With Turkey to the South & 259 & 133 & 126 & - \\
\hline With Greece to the South & 493 & 429 & 64 & - \\
\hline With Serbia to the West & 350 & 324 & 26 & - \\
\hline With Macedonia to the West & 156 & 156 & - & - \\
\hline Total length & 2245 & 1181 & 686 & - \\
\hline
\end{tabular}

Source: География на България. Физическа и социално-икономическа география, ФОРКОМ, (2002), p. 16.

19 To the North, Bulgaria borders Romania. From the Timok's outfall to the town of Silistra $(470 \mathrm{~km})$ the North border of Bulgaria follows the Danube River. The latter gives serious opportunities for the water transport. It is the largest international water road which connects Bulgaria and the countries from West and East Europe. This enables the trade between the above-mentioned countries. The regions near the Danube have the possibility to develop some industries which use a lot of water and import raw materials (producing of electricity, woodworking, chemical industry, etc.). That is why the ferries between Vidin and Calafat and between Oryahovo and Bechet (the largest in the Bulgarian-Romanian part of the river, which connects Thessaloniki and the CentralEuropean countries), as well as the bridge between Ruse and Giurgiu are of so great importance. In 2013, a second bridge on the Danube was built - between Vidin and Calafat. The ports of Lom, Vidin, and Ruse have significant economic importance, too. The port of Lom ensures the import of goods for the internal parts of the country. The Danube River is used for watering too, as well as for tourism, since along the river there are a lot of historical settlements and fortresses, as well as the lake Srebarna near Silistra.

The land border between Bulgaria and Romania (139 km long) crosses Dobrudzha, from Silistra to the village of Vama Veche on the Black Sea cost. The Dobrudzha plain enables the building of highways and railroads. This border is crossed by the Razdelna-Kardam Medgidia - Ungheni railroad (the shortest way between Bulgaria, Ukraine, and Russia), 
the Istanbul - Burgas - Varna - ConstanȚa highway, an electric transmission network from Ukraine, and a gas-pipeline from Russia.

A serious problem is the pollution of the Danube's water, of the city of Ruse, and of the towns of Nikopol, and Silistra. The governments of Bulgaria and Romania and several government and non-government organizations work for its solution. Another problem is the security of the Kozloduy Nuclear Power Plant. The perspectives for the development of the region should include an increase of the quantity of goods that go through the free trade zones in Vidin and Ruse and improvement of the transportation system through the border (ГЕОГРАФИЯ, 1997).A second nuclear power plant is going to be built near the town of Belene.

To the east, Bulgaria borders only the Black Sea - from cape Kartal (south of Vama Veche) to the outfall of the Rezovska River (total length $-378 \mathrm{~km}$ ). The width of the coastal waters is $20 \mathrm{~km}$. The Black Sea has a strategic importance: through the Bosphorus strait and the Dardanelles it is connected to the Mediterranean Sea and the Atlantic Ocean, and in this way oil, coal, coke, iron-ore, wood are imported into the country. The majority of the goods come from Russia and Ukraine. Through the ferry Varna-Illichivsk, the economic relations between Bulgaria and Ukraine improved. The Black Sea coast turned into an important economic zone. The chemical industry, the engineering industry, etc. are being developed. In the Black Sea, the fishing industry is being developed too. Its main centres are Burgas, Varna, and Sozopol. Significant amounts of salt, iodine containing algae, etc. are obtained. The Black Sea coast provides perfect conditions for tourism. Besides the beaches, there are possibilities for medical tourism, scuba diving, fishing, and so on. There are some problems, however, regarding the Black Sea. The biggest one is the pollution of its waters caused by the polluted big rivers, such as the Danube, the Dnieper, the Dniester, and the lesser ones flowing into the sea from the Bulgarian territory. Due to the limited self-cleaning abilities of the sea, the fish quantity has decreased, and the changes in the biocoenosis are scaring. Another serious problem is the landslide and the industrial pollution around Varna, Devnya, and Burgas.

To the south, Bulgaria borders Turkey and Greece. The border between Bulgaria and Turley $(259 \mathrm{~km})$ begins from the outfall of the Rezovska River and follows it to the west. Then, it crosses Strandzha and the Tundzha River and reaches the Maritza River at Kapitan Andreevo. The border between Bulgaria and Greece $(493 \mathrm{~km})$ begins from the Maritza River, crosses the Arda River, then bends to the west and crosses the Rhodopes (through the Makaza Pass, Tzigansko Gradishte peak, etc.). After crossing the Dospat and the Mesta rivers, it follows the Slavyanka Mountain, crosses the Struma River (near Kulata), and following the ridge of the Belasitza Mountain reaches Tumba peak. Despite the rugged terrain, important highways and railroads cross this borders: the highway between West Europe and the Near East (the part from Belgrade to Istanbul) through Kapitan Andreevo border check point. Of big importance is the international highway ConstanȚa - Varna Burgas - Malko Turnovo - Lozengrad - Istanbul. The Makaza Pass and the valleys of the Mesta and the Struma rivers connect Bulgaria with the Aegean Sea. On the BulgarianTurkish border, there are three border checkpoints: Malko Turnovo, Kapitan Andreevo and Lesovo. Besides, there are old roads that could be restored.

24 The relations between Bulgaria and its south neighbours are good nowadays, unlike the relations during the communist regime. 

from Tumba peak, crosses the Strumeshnitza River, then follows the ridges of the Ograzhden, Malashevska, Vlahina, and Osogovo mountains, passes through Kitka peak, the region called Kraishte, the valley of the Dragovishtitza River, Milevska Mountain, the Erma River, Ruy Mountain, and the valley of the Nishava River. Then it follows the ridge of the West Stara Planina and reaches the valley of the Timok River and the Danube. On the border between Bulgaria and Macedonia, there are three border checkpoints: Zlatarevo, Stanke Lisichkovo, and Gyueshevo. During this research, a railroad connecting the two countries has not been built yet. Such one is going to be built between Gyeshevo and Kumanovo. (and by a railroad)which connects West Europe and the Near East via Belgrade, Sofia, and Istanbul. At present, the border checkpoints between Kula and Zaječar as well as between Bregovo and Negotin are not used efficiently. The Bulgarian part does not mind the restoration of the connections between Belogradchik and Knjaževac, Tran and Klisura, Dragovishtitza and Bosilegrad, either. The free trade zone near Dragoman should be used more efficiently. The regions near the west border of Bulgaria are economically weak, the demographic situation and the social infrastructure are bad (ГЕОГРАФИЯ, 2002).

So far, the Bulgarian state borders have been presented. However, it is more important to estimate their importance regarding the economy of the country. In order to do this, a method created by Simonov (симонов, 1970) and developed by Kolev (колев,2008) is used. On the whole, it consists of a comparison between the total length of the border between two countries and its relation to the total lengths of their land borders. If the total length of a country's land border is designated by $\mathrm{S}$, the total length of its neighbour is designated by $\mathrm{S}_{1}$, and the length of the common border between them is designated by $\mathrm{D}$, the relation between them is designated like this:

When there is an equation (complete or approximate), then the common border between the two countries is equally important for them. Otherwise it has a greater importance for one of the two countries. It must be stated that this method is used only for comparison between land borders or river borders, and the necessary initial information is shown in table №4.

Table 4: Length of the land borders of Bulgaria and its neighbours in $\mathrm{km}$

\begin{tabular}{|l|l|l|}
\hline Country & Common border with Bulgaria & Total length of its borders \\
\hline Bulgaria & - & 1808 \\
\hline Macedonia & 148 & 766 \\
\hline Serbia & 318 & 2322 \\
\hline
\end{tabular}




\begin{tabular}{|l|l|l|}
\hline Romania & 608 & 2508 \\
\hline Greece & 494 & 1222 \\
\hline Turkey & 240 & 2648 \\
\hline
\end{tabular}

source: Central Intelligence Agency (CIA) - World Factbook, 2014.

Here, the total length of Bulgaria's land borders (including the Danube) is designated by $\mathrm{S}$, the total length of the land borders of its neighbours is designated by $\mathrm{S}_{1}$, and the border between Bulgaria and all of its neighbours is designated by D (колев, 2008). When these symbols are replaced by the numbers, shown in the table, and the necessary calculations are made, one can see the following relations:

$\underline{\mathrm{D} \text { (Bulgaria-Macedonia) }}=\underline{148}=0,082$ and D (Bulgaria-Macedonia) $)=\underline{148}=0,193$.

$\mathrm{S}$ (Bulgaria) $1808 \mathrm{~S}_{1}$ (Macedonia) 766

Otherwise, 0,082 < 0,193, which means that the border between Bulgaria and Macedonia has a greater significance (more than two times) for Macedonia than for Bulgaria. This was proved during the embargo against former Yugoslavia. Regarding the border between Bulgaria and Serbia, the relation is as follows:

$\underline{\mathrm{D} \text { (Bulgaria-Serbia) } 318}=0,176$ and D (Bulgaria-Serbia) $=318$

S (Bulgaria) $1808 \mathrm{~S}_{1}$ (Serbia) 2322

Obviously, $0,176>0,137$, which means that the common border is more important for Bulgaria than for Serbia. For the former, this is the shortest land road to Central and West Europe, and for the latter, it is the shortest way to Turkey, the Near and Middle East.

The calculation regarding the Bulgarian-Romanian border shows the following results:

$\underline{\text { D (Bulgaria-Romania) } 608}=0,336$ and D (Bulgaria-Romania) $=608$

S (Bulgaria) $1808 \mathrm{~S}_{1}$ (Romania) 2508

Since $0,336>0,242$, one can see that this border is more important for Bulgaria. Undoubtedly, this is true mostly for the Danubian part of the border which connects Bulgaria with many European countries not only to the West but also to the East.

A more interesting and unexpected result is seen regarding the Bulgarian-Greek border:

$\underline{\mathrm{D} \text { (Bulgaria-Greece) }}=\underline{494}=0,273$ and D (Bulgaria-Greece) $=\underline{494}=0,404$.

$\mathrm{S}$ (Bulgaria) $1808 \mathrm{~S}_{1}$ (Greece) 1222

Since $0,273<0,404$, that means that the common border is more important for Greece than for Bulgaria. This could be explained with the fact that this longest part of the Greek land border gives that country the most important possibilities for cooperation not only with its neighbours but with the rest of the EU countries.

The calculation concerning the Bulgarian-Turkish border shows the following:

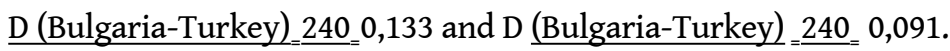

S (Bulgaria) $1808 \mathrm{~S}_{1}$ (Turkey) 2548

The inequality 0,133>0,091 makes it clear that the common border is more important for Bulgaria than for Turkey whose foreign trade is carried out mostly by sea. It is obvious 
that this border is the only connection between Bulgaria and the countries from the Near and the Middle East (колев, 2008).

\section{Formation of the Bulgarian territory throughout the centuries.}

In this respect, most important for the economic, political, and cultural development of the country is its crossroad location (on the border between Europe and Asia). Even during the time of The First Bulgarian State the country suffers from its geographic location and the historical conditions, being a neighbour of the Byzantine Empire which ruled over Bulgaria for about two centuries. The geographic and political situation on the Balkans change when they are conquered by the Turks. For centuries Bulgaria is dependent from the Ottoman feudal system which is characterized by strong central power. This feudal system slows down the Bulgarian social and economic development in comparison to other European countries. After the end of the $18^{\text {th }}$ century the Bulgarian social development is strongly influenced by the so-called Eastern Question. For more than two centuries the Balkans and South-East Europe are a problematic area of rivalry between Russia and the Western Great Powers. The first official document which shows the borders of the Bulgarian political territory is the Sultan's Decree from 1870 which establishes the Bulgarian Exarchy. The Bulgarian political borders are outlined again by the Great Powers after the April Uprising and the Constantinople Conference (1876-1877 г.). After the Russo-Turkish War (1877-1878 г.), the Preliminary Treaty of San Stefano determines the first official ethnic borders of the new Bulgarian state in whose territory is included Northern Bulgaria, including Southern Dobrudzha (as far as the line Cernavodă- Mangalia), and Southern Bulgaria - 160000 km² (Fig.№3). 
Figure 3: The Bulgarian territory according the resolutions of the Preliminary San Stefano Treaty and the Congress of Berlin



SOURCE: Bulgaria-San Stefano (1878) byTodorBozhinov.png

At the Congress of Berlin (1878 г.), the Berlin Treaty is signed, which divides Bulgaria in two parts: Principality of Bulgaria (including Northern Bulgaria and the region around Sofia, covering an area of 63000 square $\mathrm{km}$ ), and Eastern Rumelia (a tributary subject of Turkey). After the Unification of Principality of Bulgaria with Eastern Rumelia, (covering an area of 98000 square $\mathrm{km}$ ), the Bulgarian borders are recognized by all Great Powers but the country has no exit to the Aegian Sea. After the Balkan War and the Treaty of London (1913), Turkey gives back to Bulgaria a territory of about 23000 square km,and Macedonia is divided between Greece and Serbia. The region around the Pirin Mountains and the Western Outlands are annexed to Bulgaria, and its territory covers about 111000 square $\mathrm{km}$. The dissatisfaction in the country from the outcome of the Balkan War leads to a new war -the Second Balkan War in which Bulgaria is defeated. According to the judgments of the Treaty of Bucharest, Bulgaria is deprived of Southern Dobrudzha (7700 square $\mathrm{km}$ ), Eastern Thracia, Aegian Macedonia, and the Western Outlands, and its territory is diminished to 103000 square $\mathrm{km}$. The Treaty of Neuilly-sur-Seine divides Bulgaria again and it is deprived of Southern Dobrudzha (which is given to Romania), the Western Outlands and Macedonia (given to Serbia), and Eastern Thrace (given to Greece). In this way, about 50000 square $\mathrm{km}$, inhabited by Bulgarians, are taken of Bulgaria. In 1940, Southern Dobrudzha is given back to Bulgaria (according the resolutions of the Treaty of Craiova). The Bulgarian territory spreads over 111000 square $\mathrm{km}$ again. In the period between 1941 and 1945, Macedonia and Aegian Thrace are temporarily annexed to Bulgaria, but after the Treaty of Paris (1947) they are given back to Yugoslavia and Greece (ГЕОГРАФИЯ, 1997). 
After the end of the Cold War, the new geopolitical situation on the Balkans and in Europe leads to changes in the relations between the Balkan countries. Their borders and the border areas turn into zones of intensive cooperation. As a result, there is a process of regional (Balkan) and continental (European) integration of Balkan countries, including Bulgaria. This process is facilitated by Bulgaria's membership in NATO and the EU.

\section{BIBLIOGRAPHY}

ГЕОГРАФИЯНАБЪЛГАРИЯ. ФИЗИЧЕСКА И ИКОНОМИЧЕСКАГЕОГРАФИЯ. СОФИЯ, АИ

„МАРИНДРИНОВ“, 1997.

ГЕОГРАФИЯНАБЪЛГАРИЯ. ФИЗИЧЕСКА И СОЦИАЛНО-ИКОНОМИЧЕСКАГЕОГРАФИЯ, ФОРКОМ, СОФИЯ, 2002.

ДИМИТРОВ, СЛАВИ. ТРАНСГРАНИЧНОТОСЪТРУДНИЧЕСТВОМЕЖДУИСПАНИЯ И ПОРТУГАЛИЯ, 2015 (In print).

ДРОНЧИЛОВ, КРУМ. ПОЛИТИЧЕСКАТАГРАНИЦА. In: ПОЛИТИЧЕСКАГЕОГРАФИЯ И ГЕОПОЛИТИКА В ОРИГИНАЛ. КЛАСИЦИТЕ 1. СБОРНИКОТСТАТИИ. СЪСТАВИТЕЛИ: М. РУСЕВ, Г. РАЧЕВ, СОФИЯ, 2003.

КАРАСТОЯНОВ, СТЕФАН. ПОЛИТИЧЕСКАГЕОГРАФИЯ. ГЕОПОЛИТИКА. ГЕОСТРАТЕГИЯ. „СВ. КЛИМЕНТОХРИДСКИ", СОФИЯ, 1997.

КОЛЕВ, БОРИС. НАЦИОНАЛНОТОГЕОГРАФСКОПРОСТРАНСТВОНА РЕПУБЛИКАБЪЛГАРИЯ, „ХЕРОНПРЕС”, СОФИЯ, 2008.

НСИ (НАЦИОНАЛЕНСТАТИСТИЧЕСКИИНСТИТУТ), СОФИЯ, 2014.

ПЕНИН, РУМЕН. ПРИРОДНАГЕОГРАФИЯНАБЪЛГАРИЯ. „БУЛВЕСТ”, СОФИЯ, 2007.

Central Intelligence Agency (CIA) - World Factbook, 2014.

RATZEL, Friedrich. Politische Geographie. Munich et Leipzig, 1897.

\section{ABSTRACTS}

The article examines the geographic location of Bulgaria. The geographic location of a country can be astronomical, natural, economic, and political. It traces the changes in the territory of Bulgaria from 1878 until the end of World War II. The article features the borders of Bulgaria and its neighbors in economic and political perspective. This is useful, given the relations between Bulgaria and the neighboring countries: Romania, Serbia, Macedonia, Greece and Turkey. After the end of the Cold War, the new geopolitical situation in the Balkan and in Europe leads to changes in the relations between the Balkan countries. Their borders and the border areas turn into zones of intensive cooperation. As a result, there is a process of regional integration between Balkan countries, including Bulgaria, and from them with Europe also. This process is facilitated by Bulgaria's membership in NATO and the EU. The article used modern research methods, figures, tables and schematic map. 
O artigo examina a localização geográfica da Bulgária sob o ponto de vista astronômico e natural mas, principalmente, em termos econômicos e políticos a fim de retraçar suas mudanças territoriais entre 1878 a 1945 - incluindo suas relações com os vizinhos Romênia, Sérvia, Macedônia, Grécia e Turquia. Após o fim da Guerra Fria, a nova situação geopolítica internacional modifica o diálogo entre os países balcânicos. Suas fronteiras e áreas limítrofes tornaram-se zonas de intensa cooperação, e o resultado disto é um processo de integração regional (Balcãs) e continental (Europa), facilitado pela adesão da Bulgária à OTAN e à União Européia.

L'article examine l'emplacement géographique (sous le point du vue astronomique et naturel, mais surtout en termes économique et politique) de la Bulgarie à fin de retracer ses changements territoriales de 1878 à 1945 - y compris les relations avec ses voisins Roumaine, Serbie, Macécoine, Grèce et Turquie. Après la fin de la Guerre Froide, la nouvelle situation géopolitique internationale modifie le dialogue entre les pays des Balkans. Leurs frontières et leurs zones frontalières se transforment en espaces de coopération intensive, et le résultat c'est un processus d'intégration régionale (au niveau des Balkans) et continentale (au niveau de l'Europe) aidée par l'adhésion de la Bulgarie à l'OTAN et à l'Union Européenne.

El artículo analiza la situación geográfica de Bulgaria. La ubicación geográfica de um país puede ser astronómica, natural, económica y política. Traza los cambios en el territorio de Bulgaria desde 1878 hasta el final de la Segunda Guerra Mundial. Aún así, el muestra las fronteras de Bulgaria y de sus vecinos en una perspectiva económica y política. Esto es útil, dadas las relaciones entre Bulgaria y los países vecinos: Rumania, Serbia, Macedonia, Grecia y Turquía. Tras el final de la Guerra Fría, la nueva situación geopolítica em los Balcanes y en Europa lleva a los cambios en las relaciones entre los países de los Balcanes. Sus fronteras y las zonas fronterizas se convierten en zonas de intensa cooperación. Como resultado, hay un proceso de integración regional (Balcanes) y continental (europeo) de los países de los Balcanes, entre ellos Bulgaria. Este proceso se ve facilitado por la pertenencia de Bulgaria en la OTAN y la UE.

\section{INDEX}

Mots-clés: géographie, Guerre Froide, Union Européenne, OTAN, voisinage des Balkans.

Palavras-chave: geografia, Guerra Fria, União Européia, OTAN, vizinhança balcânica.

Palabras claves: geografía, la Guerra Fría, la Unión Europea, la OTAN, los vecinos de los Balcanes

Keywords: geography, Cold War, European Union, NATO, Balkans neighbors.

\section{AUTHOR}

\section{SLAVI DIMITROV}

Ph. D. Associate Professor in the St. Cyril and St Methodius University of Veliko Turnovo, Bulgaria. Email: slavi_omurtag@abv.bg 